\title{
Dynamic-chemical coupling of the upper troposphere and lower stratosphere region
}

\author{
Volker Grewe, ${ }^{1}$ Drew T. Shindell \\ NASA Goddard Institute for Space Studies and Center for Climate Systems Research, Columbia \\ University, New York, New York \\ Christian Reithmeier \\ Deutsches Zentrum für Luft- und Raumfahrt, Institut für Physik der Atmosphäre, \\ Oberpfaffenhofen, Germany
}

Abstract. The importance of the interaction of chemistry and dynamics in the upper troposphere and lower stratosphere for chemical species like ozone is investigated using two chemistry-climate models. Species emitted in the upper troposphere, like $\mathrm{NO}_{\mathrm{x}}$ $\left(=\mathrm{NO}+\mathrm{NO}_{2}\right)$ by lightning or aircraft, have the chance to be transported into the lowermost stratosphere. Trajectory calculations suggest that the main transport pathway runs via the Inter Tropical Convergence Zone, across the tropical tropopause and then to higher latitudes, i.e. into the lowermost stratosphere. Longer lifetimes of $\mathrm{NO}_{\mathbf{x}}$ in the lower stratosphere yield an accumulation of $\mathrm{NO}_{x}$ there, which feeds back on upper troposphere chemistry. This effect has been estimated for lightning $\mathrm{NO}_{\mathrm{x}}$ emissions and reveals a contribution of at least $25 \%$ to $40 \%$ to the total northern hemisphere mid-latitude lightning increase of either $\mathrm{NO}_{\mathrm{x}}$ and ozone.

\section{Introduction}

Increasing attention has been paid to effects of aircraft emissions [Brasseur et al., 1998; IPCC, 1999] and lightning emissions [e.g. Stockwell et al., 1999; Grewe et al., 2000] on the chemical atmospheric composition. Lightning and aircraft are the only two direct $\mathrm{NO}_{\mathbf{x}}$ $\left(=\mathrm{NO}+\mathrm{NO}_{2}\right)$ emitters in the upper troposphere. Their impact on climate via production of ozone and destruction of $\mathrm{CH}_{4}$ has been discussed on the basis of model simulations [IPCC, 1999]. Most of these models include detailed troposphere chemistry and some kind of upper boundary condition between 50 and $100 \mathrm{hPa}$ to represent stratospheric chemistry. However, the impact of an upper boundary condition at these altitudes on estimates regarding the upper troposphere has not yet been investigated.

Holton et al. [1995] presented principal transport patterns concerning stratosphere-troposphere exchange: Isentropic mixing from the upper tropical troposphere to the mid-latitude lowermost stratosphere and large-scale 
tropical ascent and isentropic transport to higher latitudes are the main transport mechanisms by which upper troposphere tropical air masses may influence the lower stratosphere at higher latitudes. Estimation of the effects of emissions in the upper troposphere are strongly influenced by these transport pathways, since emissions of $\mathrm{NO}_{\mathbf{x}}$ may accumulate in the lowermost stratosphere, where its lifetime greatly exceeds its tropospheric lifetime. The present paper aims at investigating the effect of a coupling of troposphere and stratosphere chemistry and dynamics. Using the Lagrangian transport algorithm ATTILA [Reithmeier, 2000] trajectory calculations provide information about the pathways of species emitted in the upper troposphere. The coupled chemistry-climate model ECHAM4.L39(DLR)/CHEM of the troposphere and lower stratosphere and the troposphere GISS chemistry-climate model will be used to investigate the importance of troposphere-stratosphere coupling, exemplary for lightning emissions.

\section{Brief model descriptions}

The Lagrangian transport scheme ATTILA [Reithmeier, 2000] has been developed on the basis of the chemistry transport model STOCHEM [Collins et al., 1997]. It has been coupled to ECHAM4, in a way that full information is provided at every time-step. It includes state-of-the-art parameterizations for turbulent mixing within the boundary layer [Maryon et al., 1991], diffusion [Walton et al., 1988], and convection [Brinkop and Sausen, 1997].

The coupled climate-chemistry model ECHAM4.L39(DLR)/CHEM

[Hein et al., 2000; Land, 1999] is based on the spectral general circulation model (GCM) ECHAM4 [Roeckner et al., 1996] with increased vertical resolution $(700 \mathrm{~m}$ at tropopause altitudes). The chemical module [Steil et al., 1998] has already been coupled to ECHAM3 and used in a variety of studies regarding the tropospheric and stratospheric chemistry [e.g. Grewe et al., 1999]. It includes stratospheric heterogeneous and homogeneous ozone chemistry and tropospheric $\mathrm{NO}_{\mathrm{x}}-\mathrm{CH}_{4}-\mathrm{CO}-\mathrm{OH}-$ $\mathrm{O}_{3}$-chemistry with 107 photochemical reactions and 37 species.

The GISS II' ('two prime') GCM [Hansen et al., 1997] was developed from the GISS GCM version II. GISS II' has 9 'sigma' coordinate levels leading to a vertical resolution at the tropopause of 3 to $4 \mathrm{~km}$. A chemistry module has been coupled to the GCM including 52 reactions of 24 species for tropospheric chemistry [Shindell et al., 2000]. It describes mainly the same chemistry like CHEM, but also takes into account $\mathrm{N}_{2} \mathrm{O}_{5}$ hydrolysis on sulfate aerosol. Ozone, $\mathrm{NO}_{\mathrm{x}}$, and $\mathrm{NO}_{y}$ are prescribed 
at $110 \mathrm{hPa}$.

Peroxyacetyl nitrate (PAN) and explicit non-methane hydrocarbon (NMHC) chemistry is omitted in both models. Surface $\mathrm{NO}_{\mathrm{x}}$ emissions of 33.1 and $38.1 \mathrm{TgN}$ per year, and aircraft $\mathrm{NO}_{\mathrm{x}}$ emissions of 0.56 and $0.51 \mathrm{TgN}$ per year are included in the ECHAM4.L39(DLR)/CHEM and the GISS model, respectively. The lightning parameterizations generate $\mathrm{NO}_{\mathbf{x}}$ interactively with the convection scheme [Price et al., 1994].

The two climate-chemistry models differ mainly in the vertical resolution, the treatment of stratospheric chemistry and the overall transport characteristics, and less in the description of tropospheric chemistry.

\section{Transport of species emitted in the upper troposphere}

To investigate the transport pathways of emitted species the Lagrangian transport scheme ATTILA has been applied on the basis of an ECHAM4 presentday climate simulation. Two different idealized emission sources and regions have been defined. An aircraft source (A) and a tropical lightning source (L), which both are located in the upper troposphere (150$300 \mathrm{hPa}$ ) but at different latitudes, i.e. $20^{\circ} \mathrm{N}-50^{\circ} \mathrm{N}$ and $20^{\circ} \mathrm{S}-20^{\circ} \mathrm{N}$, respectively. For each region 10,000 air parcels have been released. After one year of integration 85 to $90 \%$ (Table 1) of the air parcels are in the troposphere $(\mathrm{T})$ and 4 to $5 \%$ in the lowermost stratosphere (LMS). Since the regions themselves are of very different volume and mass, a mass related comparison offers the best basis for the interpretation of the results concerning the importance of upper troposphere emissions for these regions. The density of air parcels originating from the source regions $\mathrm{A}$ and $\mathrm{L}$ and the contribution to the total mass in the lowermost stratosphere is around $60 \%$ of the corresponding tropospheric contributions (Table 1). This clearly reveals the importance of the coupling of the lowermost stratosphere and upper troposphere for investigations concerning upper troposphere emissions.

Figure 1 shows how air parcels are transported from the two sources regions $\mathrm{A}$ and $\mathrm{L}$ to the lowermost stratosphere. Most of these air parcels (more than $85 \%$ for the aircraft source and more than $70 \%$ for the lightning source) are first transported downwards and then, at the Inter Tropical Convergence Zone (ITCZ), upwards into the lower tropical stratosphere. Meridional transport moves those air parcels to the lowermost stratosphere of both hemispheres. Therefore species emitted in the upper troposphere are mainly entering the lowermost stratosphere via transport across the tropical 
tropopause. They may then even return to the upper troposphere by a downward flux from the stratosphere to the troposphere in the extra-tropics.

\section{Impact of lightning $\mathrm{NO}_{\mathrm{x}}$ emissions on the chemistry}

Considering these transport pathways, the effect of lightning $\mathrm{NO}_{\mathrm{x}}$ emissions is studied with the ECHAM4.L39(DLR)/CHEM model and the GISS model, which have upper boundaries for $\mathrm{NO}_{y}$ and $\mathrm{NO}_{x}$ at $10 \mathrm{hPa}$ and $110 \mathrm{hPa}$, respectively. Additionally, ECHAM4.L39(DLR)/CHEM has been applied with an upper boundary at $80 \mathrm{hPa}$, with values for $\mathrm{NO}_{\mathrm{y}}$ derived from the simulation with the $10 \mathrm{hPa}$ upper boundary. For each of those three modeIs, 2 simulations for the year 1990 were performed: one with and one without emissions of $\mathrm{NO}_{\mathrm{x}}$ from lightning. A 5 year simulation length is considered after a spin up time. Figure 2 views the results for nitrous oxide and ozone. It clearly shows that ECHAM4.L39(DLR)/CHEM allows for an accumulation of $\mathrm{NO}_{\mathrm{x}}$ in the upper troposphere and lower stratosphere. Maximum relative changes are found in the tropical stratosphere and upper troposphere, where $\mathrm{NO}_{\mathrm{x}}$ is more than four times higher than in the experiment without the $\mathrm{NO}_{\mathrm{x}}$ lightning source. Ozone is increased by $70 \%$ in the upper tropical troposphere and also shows increases at higher latitudes. Introducing an upper boundary at $80 \mathrm{hPa}$ strongly reduces the effect of lightning emissions. The maximum tropospheric $\mathrm{NO}_{\mathrm{x}}$ increase is still at $200 \mathrm{hPa}$, but strongly reduced. However, below that region only small differences occur between the 2 simulations. Nitrogen oxides at southern and northern mid and high latitudes are much less influenced by lightning. The GISS model, which has the $\mathrm{NO}_{x}$ upper boundary at $110 \mathrm{hPa}$, shows a similar pattern of the lightning induced $\mathrm{NO}_{\mathrm{x}}$ changes as the ECHAM4.L39(DLR)/CHEM model with the lowered upper boundary condition. In the tropics relative changes due to lightning are $50 \%$ less. However, absolute changes are similar. The increase at higher northern latitudes mainly results from lightning occurring in the extra-tropics. Ozone changes are only found in the tropics, peaking in the middle troposphere.

The differences in the calculated impact of the lightning $\mathrm{NO}_{\mathrm{x}}$ emissions can largely be attributed to the suppressed transport mechanisms, as shown in the previous section. The contribution of this tropospherestratosphere dynamical-chemical coupling is estimated in Table 2. In the extra-tropical upper troposphere $(225 \mathrm{hPa}$ to $350 \mathrm{hPa})$ this contribution to the enhancement of the $\mathrm{NO}_{\mathbf{x}}$ and $\mathrm{NO}_{\mathrm{y}}$ due to lightning accounts 
for roughly $25 \%$ to $35 \%$ and $25 \%$ to $40 \%$, respectively. Its contribution to an ozone increase is about $35 \%$ to $40 \%$ in that region. These values are much lower in the tropical region.

More than a third of the increase of ozone due to lightning at northern mid and high latitudes can therefore be attributed to tropical $\mathrm{NO}_{\mathbf{x}}$ emissions, which is $10 \%$ of the $\mathrm{NO}_{\mathrm{x}}$ concentration there. In the southern hemisphere it is even $15 \%$, since the background $\mathrm{NO}_{\mathrm{x}}$ concentration is smaller, but the coupling mechanism effects uniformly both hemispheres.

Taking into account that the lowered upper boundary $(80 \mathrm{hPa})$ still allows some transport from the tropical troposphere to the lowermost stratosphere, these estimates can only be lower limits for the ECHAM4.L39(DLR)/CHEM.

This is supported by the GISS model, which allows no such transports and shows no significant ozone changes at mid latitudes.

\section{Discussion and Conclusion}

Applying a Lagrangian trajectory model, we showed that species emitted in the northern upper troposphere, e.g. $\mathrm{NO}_{\mathrm{x}}$ by aircraft or lightning, have the chance to reach the lowermost stratosphere of both hemispheres. The species are transported downwards and southwards to the tropics and then in the ITCZ into the tropical stratosphere and afterwards to the lowermost stratosphere. Almost all trajectories from the northern upper troposphere to the lowermost stratosphere showed this pathway. For the trajectory simulations, no sinks have been taken into account, since we only focused on the principal transport pathways. The dynamicalchemical simulations, which include sinks and sources for nitrogen species, clearly show the long range impacts. This transport pathways give a reasonable explanation of how species released by aircraft, mainly flying on the northern hemisphere, affect the southern lowermost stratosphere, as shown with aviation fuel tracer simulations [Danilin et al., 1998] and aircraft $\mathrm{NO}_{\mathrm{x}}$ simulations [Grewe et al., 1999].

By lowering the upper boundary from $10 \mathrm{hPa}$ to $80 \mathrm{hPa}$, the effect of this transport mechanism on the chemical impact of lightning has been investigated. It clearly shows a strong impact on upper troposphere $\mathrm{NO}_{\mathrm{x}}$ and ozone in the extra-tropical upper troposphere, indicating that the coupling of the upper troposphere with the lower stratosphere is essential for estimates of the chemical impacts of emissions, released in the upper troposphere. Since the trajectories pass the lower troposphere, the coupling mechanism is also relevant for surface emissions, at least in the tropics. 
Acknowledgments. This study has been supported by NASA's Atmosphere Chemistry Modeling and Analysis Program.

\section{References}

Brasseur, G.P., R.A. Cox, D. Hauglustaine, I. Isaksen, J. Lelieveld, D.H. Lister, R. Sausen, U. Schumann, A. Wahhner, and P. Wiesen, European scientific assessment of the atmospheric effects of aircraft emissions, Atmos. Environ., 32, 2329-2418, 1998.

Brinkop, S., and R. Sausen, A modified mass-flux scheme for convection which maintains positive tracer concentrations, Beitr. Phys. Atmosph., 70, 245-248, 1997.

Collins, W.J., D.S. Stevenson, C.E. Johnson, and R.G. Derwent, Tropospheric ozone in a global-scale three-dimensional Lagrangian model and its response to $\mathrm{NO}_{x}$ emission controls, J. Atmos. Chem., 26, 223-274, 1997.

Danilin M.Y., et al., Aviation fuel tracer simulation: Model intercomparison and implications, Geophys. Res. Lett., 25, 3947-3950, 1998.

Grewe, V., M. Dameris, R. Hein, I. Köhler, and R. Sausen, Impact of future subsonic aircraft $\mathrm{NO}_{\mathrm{x}}$ emissions on the atmospheric composition, Geophys. Res. Lett., 26, 47-50, 1999.

Grewe, V., D. Brunner, M. Dameris, L. Grenfell, R. Hein, and D. Shindell, The origin of upper troposphere nitrogen oxides and ozone and their variability at northern midlatitudes, submitted to Atmosph. Environm., 2000.

Hansen, J. et al., Forcings and chaos in interannual to decadal climate change, J. Geophys. Res., 102, 25,67925,720, 1997.

Hein, R., M. Dameris, C. Schnadt, C. Land, V. Grewe, I. Köhler, M. Ponater, R. Sausen, B. Steil, J. Landgraf, C. Brühl, Results of an interactively coupled atmospheric chemistry-general circulation model: comparison with observations, submitted to J. Geophys. Res., , 2000.

Holton J.R., P.H. Haynes, M.E. McIntyre, A.R. Douglass, R.B. Rood, and L. Pfister, Stratosphere-troposphere exchange, Rev. Geophys., 33, 403-439, 1995.

IPCC (Intergovernmental Panel on Climate Change), Aviation and the global atmosphere, eds. J.E. Penner, D.H. Lister, D.J. Griggs, D.J. Dokken, M. McFarland, pp. 373, Cambridge University Press, Cambridge, U.K., 1999.

Land, C., Untersuchungen zum globalen Spurenstofftransport mit dem Atmosphärenmodell ECHAM4.L39(DLR), Ph.D. thesis, Fakultät für Physik, Ludwig-MaximiliansUniversität München, Germany, 1999, available as Report No. 1991-32, DLR Oberpfaffenhofen, Weßling, Germany, ISSN 1434-8454, 1999.

Maryon, R.H., F.B. Smith, B.J. Conway, and D.M. Goddard, The U.K. nuclear accident model, Progr. Nucl. Energy, 26, 85-104, 1991.

Price, C., and D. Rind, Modeling global lightning distributions in a general circulation model, Mon. Wea. Rev., 122, 1930-1937, 1994.

Reithmeier, C., Untersuchung des Stratosphären-TroposphärenAustausches mit einem Lagrange'schen Modell, Ph.D. thesis, Fakultät für Physik, Ludwig-Maximilians-Universität München, Germany, in preparation, 2000.

Roeckner, E., K. Arpe, L. Bengtsson, M. Christoph, M. Claussen, 
L. Dümenil, M. Esch, M. Giorgetta, U. Schlese, and U. Schulzweida, The atmospheric general circulation model ECHAM4: Model description and simulation of presentday climate, Report No. 218, Max-Planck-Institut für Meteorologie, Hamburg, Germany, ISSN 0937-1060, 1996.

Shindell, D.T., J.L. Grenfell, D. Rind, P. Price, and V. Grewe, Chemistry-climate interactions in the GISS GCM. 1: Tropospheric chemistry model description and evaluation, to be submitted to Journal of Geophysical Research.

Steil, B., M. Dameris, C. Brïhl, P.J. Crutzen, V. Grewe, M. Ponater, and R. Sausen, Development of a chemistry module for GCMs: first results of a multiannual integration, Ann. Geophys. 16, 205-228, 1998.

Stockwell, D.Z., C. Giannakopoulos, P.H. Plantevin, G.D. Carver, M.P. Chipperfield, K.S. Law, J.A. Pyle, D.E. Shallcross, K.Y. Wang, Modelling NOx from lightning and its impact on global chemical fields, Atmos. Environm., 33, 4477-4493, 1999.

Walton, J.J., M.C. MacCracken, and S.J. Ghan, A globalscale Lagrangian trace species model of transport, transformation, and removal processes, J. Geophys. Res., 93, 8339-8354, 1988.

V. Grewe, D. Shindell, NASA Goddard Institute for Space Studies and Center for Climate System Research, Columbia University, 2880 Broadway, New York, NY 10025, USA. (email: vgrewe@giss.nasa.gov; dshindel@giss.nasa.gov)

C. Reithmeier, Deutsches Zentrum für Luft- und Raumfahrt (DLR), Institut für Physik der Atmosphäre, Oberpfaffenhofen, D-82234 Weßling, Germany. (email; christian.reithmeier@dlr.de)

(Received March 1, 2000; revised February 27, 1996; accepted March 31, 1996.)

${ }^{1}$ Also at Deutsches Zentrum für Luft- und Raumfahrt, Institut für Physik der Atmosphäre, Oberpfaffenhofen, Germany. 
Figure 1. Composites of trajectories which start in the source regions $A$ (left) and L (right), then are transported to the tropical $\left(20^{\circ} \mathrm{S}\right.$ to $20^{\circ} \mathrm{N}$ ) troposphere (air pressure more than $400 \mathrm{hPa}$ ) and then end in the lowermost stratosphere. Mean trajectories are calculated for each of these three paths and afterwards combined to a single trajectory. The composites include $70 \%, 100 \%$, $71 \%$, and $67 \%$ of all trajectories from the source region A to NLMS, A to SLMS, L to NLMS, and L to SLMS, respectively (see Table 1 ).

Figure 1. Composites of trajectories which start in the source regions A (left) and L (right), then are transported to the tropical $\left(20^{\circ} \mathrm{S}\right.$ to $20^{\circ} \mathrm{N}$ ) troposphere (air pressure more than $400 \mathrm{hPa}$ ) and then end in the lowermost stratosphere. Mean trajectories are calculated for each of these three paths and afterwards combined to a single trajectory. The composites include $70 \%, 100 \%, 71 \%$, and $67 \%$ of all trajectories from the source region $\mathrm{A}$ to NLMS, A to SLMS, L to NLMS, and L to SLMS, respectively (see Table 1).

Figure 2. Annual mean relative changes [\%] of $\mathrm{NO}_{\mathrm{x}}$ (left) and ozone (right) due to lightning $\mathrm{NO}_{x}$ emissions. Results are shown for the ECHAM4.L39(DLR)/CHEM models with an upper boundary at $10 \mathrm{hPa}$ (top) and $80 \mathrm{hPa}$ (middle) and for the GISS model (bottom) with an upper boundary at $110 \mathrm{hPa}$. Changes are calculated relative to a simulation without lightning emissions. All ECHAM4.L39(DLR)/CHEM results are significant at a 99\% level. In the GISS model, the light and dark shading indicates the $95 \%$ and $99 \%$ significant levels (t-test). The tropical changes of $\mathrm{NO}_{\mathbf{x}}$ due to lightning in the both models with a low upper boundary have similar absolute changes.

Figure 2. Annual mean relative changes [\%] of $\mathrm{NO}_{\mathrm{x}}$ (left) and ozone (right) due to lightning $\mathrm{NO}_{\mathrm{x}}$ emissions. Results are shown for the ECHAM4.L39(DLR)/CHEM models with an upper boundary at $10 \mathrm{hPa}$ (top) and $80 \mathrm{hPa}$ (middle) and for the GISS model (bottom) with an upper boundary at $110 \mathrm{hPa}$. Changes are calculated relative to a simulation without lightning emissions. All ECHAM4.L39(DLR)/CHEM results are significant at a 99\% level. In the GISS model, the light and dark shading indicates the $95 \%$ and $99 \%$ significant levels (t-test). The tropical changes of $\mathrm{NO}_{\mathbf{x}}$ due to lightning in the both models with a low upper boundary have similar absolute changes. 
Table 1. Share of particles [\%], its density [air parcels per air mass], and share of mass within the target regions [\%], which are transported from the source region $\AA\left(150-300 \mathrm{hPa}, 20^{\circ} \mathrm{N}-50^{\circ} \mathrm{N}\right)$ and $\mathrm{L}\left(150-300 \mathrm{hPa}, 20^{\circ} \mathrm{S}-\right.$ $\left.20^{\circ} \mathrm{N}\right)$ to the stratosphere ' $\mathrm{S}$ ' $(\leq 150 \mathrm{hPa})$, northern lower-most stratosphere 'NLMS' $\left(150-250 \mathrm{hPa}, 20^{\circ} \mathrm{N}-\right.$ $90^{\circ} \mathrm{N}$ ), southern lower-most stratosphere 'SLMS' (150 $250 \mathrm{hPa}, 20^{\circ} \mathrm{S}-90^{\circ} \mathrm{S}$ ), and the troposphere ' $\mathrm{T}$ ' (rest).

\begin{tabular}{llccccc}
\hline & & Region & T & NLMS & SLMS & S \\
\hline Share of & {$[\%]$} & A & 87.9 & 2.3 & 2.0 & 7.8 \\
particles & {$[\%]$} & $\mathrm{L}$ & 86.0 & 2.5 & 2.5 & 9.0 \\
Particle & {$\left[\left(10^{16} \mathrm{~kg}\right)^{-1}\right]$} & A & 21 & 14 & 12 & 10 \\
density & {$\left[\left(10^{16} \mathrm{~kg}\right)^{-1}\right]$} & $\mathrm{L}$ & 21 & 14 & 14 & 10 \\
Mass & {$[\%]$} & A & 3.6 & 2.3 & 2.0 & 1.7 \\
fraction & {$[\%]$} & $\mathrm{L}$ & 5.6 & 3.8 & 3.9 & 3.1 \\
& & & & & & \\
\hline
\end{tabular}


Table 2. Relative contribution [\%] of the tropospherestratosphere coupling to the lightning induced enhancement of $\mathrm{NO}_{\mathrm{x}}, \mathrm{NO}_{\mathrm{y}}$, and ozone in the upper troposphere $(225-350 \mathrm{hPa})$. The contribution [\%] of the tropospherestratosphere coupling relative to the background concentration is given in brackets.

\begin{tabular}{rrrrrr}
\hline & $90^{\circ} \mathrm{N}$ & $60^{\circ} \mathrm{N}$ & $30^{\circ} \mathrm{N}$ & $30^{\circ} \mathrm{S}$ & $60^{\circ} \mathrm{S}$ \\
& $-60^{\circ} \mathrm{N}$ & $-30^{\circ} \mathrm{N}$ & $-30^{\circ} \mathrm{S}$ & $-60^{\circ} \mathrm{S}$ & $-90^{\circ} \mathrm{S}$ \\
\hline $\mathrm{NO}_{\mathbf{x}}$ & $34(10)$ & $26(10)$ & $5(4)$ & $19(14)$ & $23(14)$ \\
$\mathrm{NO}_{\mathrm{y}}$ & $39(8)$ & $26(9)$ & $8(7)$ & $22(15)$ & $26(14)$ \\
$\mathrm{O}_{3}$ & $41(6)$ & $34(7)$ & $17(8)$ & $28(11)$ & $29(10)$ \\
\end{tabular}

GREWE ET AL.: THE COUPLING OF THE TROPOPAUSE REGION

GREWE ET AL.: THE COUPLING OF THE TROPOPAUSE REGION

GREWE ET AL.: THE COUPLING OF THE TROPOPAUSE REGION

GREWE ET AL: THE COUPLING OF THE TROPOPAUSE REGION

GREWE ET AL:: THE COUPLING OF THE TROPOPAUSE REGION

GREWE ET AL.: THE COUPLING OF THE TROPOPAUSE REGION

GREWE ET AL.: THE COUPLING OF THE TROPOPAUSE REGION

GREWE ET AL.: THE COUPLING OF THE TROPOPAUSE REGION

GREWE ET AL.: THE COUPLING OF THE TROPOPAUSE REGION

GREWE ET AL.: THE COUPLING OF THE TROPOPAUSE REGION

GREWE ET AL.: THE COUPLING OF THE TROPOPAUSE REGION

GREWE ET AL.: THE COUPLING OF THE TROPOPAUSE REGION

GREWE ET AL.: THE COUPLING OF THE TROPOPAUSE REGION

GREWE ET AL.: THE COUPLING OF THE TROPOPAUSE REGION

GREWE ET AL.: THE COUPLING OF THE TROPOPAUSE REGION

GREWE ET AL.: THE COUPLING OF THE TROPOPAUSE REGION

GREWE ET AL.: THE COUPLING OF THE TROPOPAUSE REGION

GREWE ET AL.: THE COUPLING OF THE TROPOPAUSE REGION 
GREWE ET AL.: THE COUPLING OF THE TROPOPAUSE REGION GREWE ET AL.: THE COUPLING OF THE TROPOPAUSE REGION 

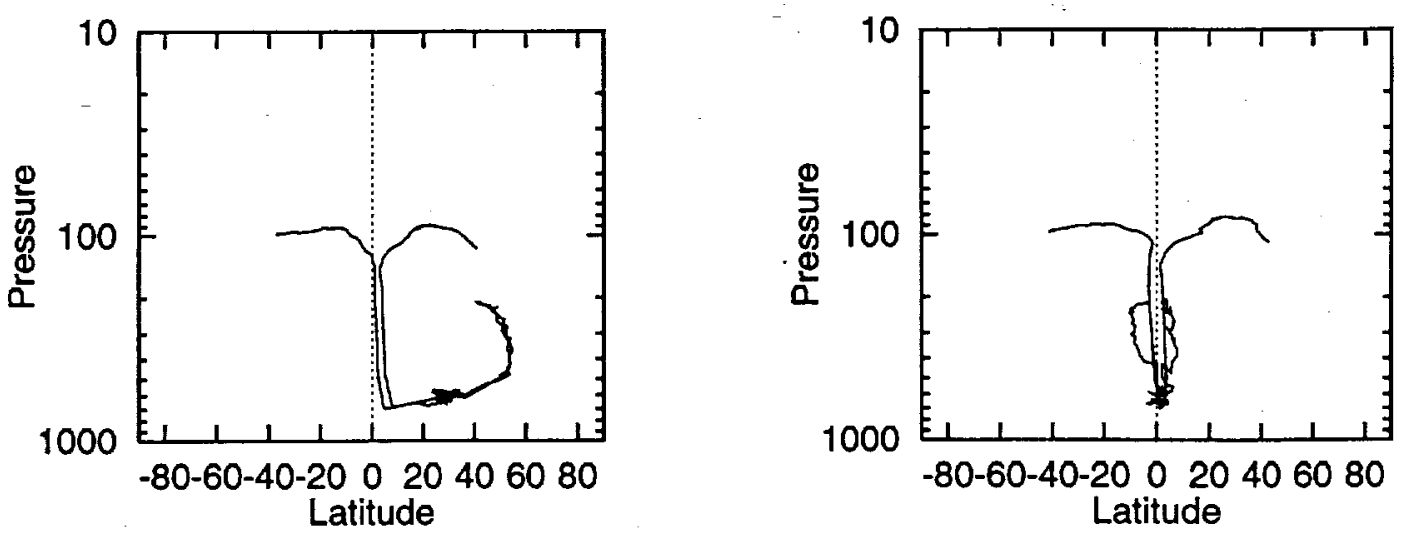
$\mathrm{NO}_{\mathrm{x}}$
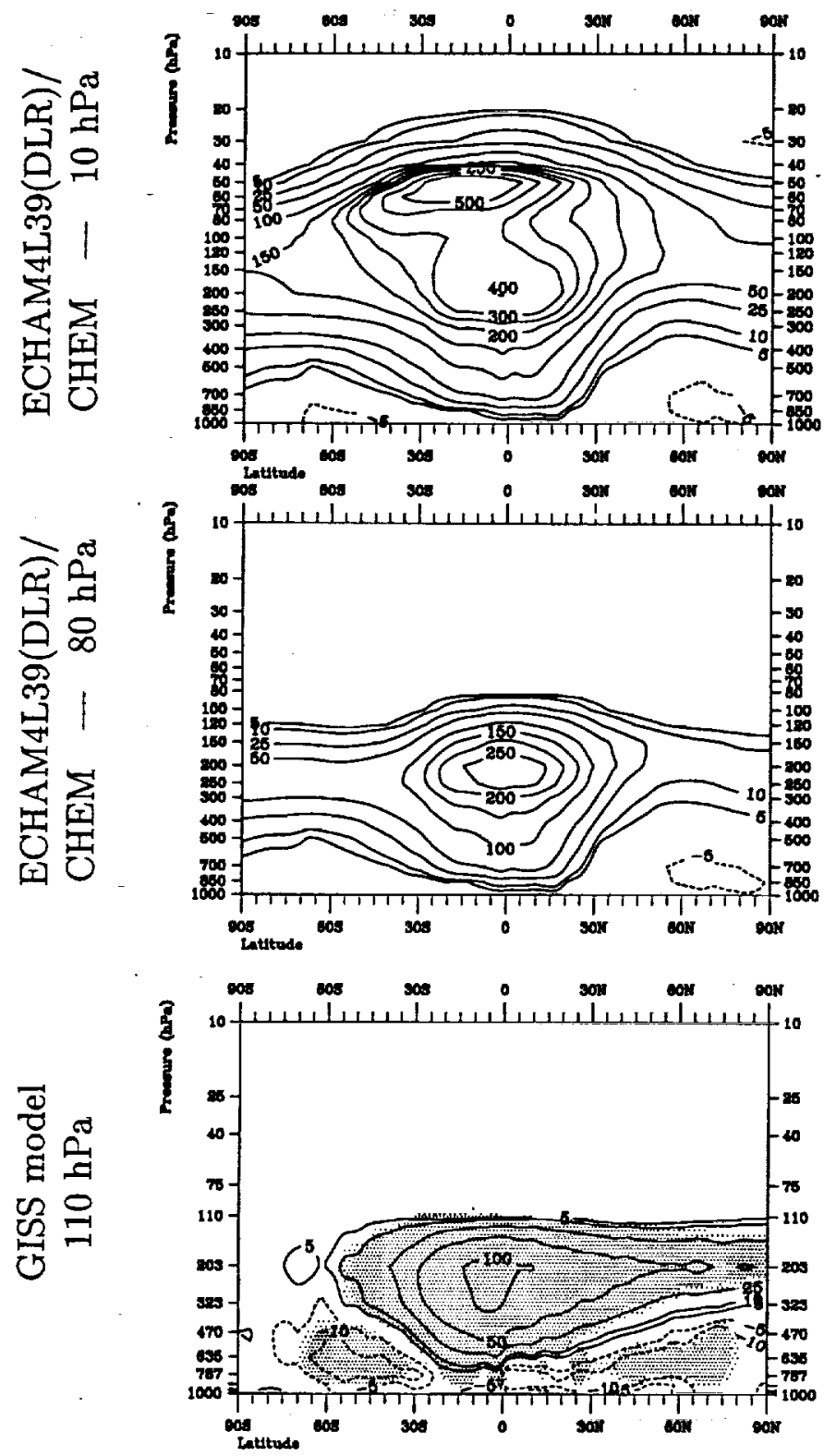

$\mathrm{O}_{3}$
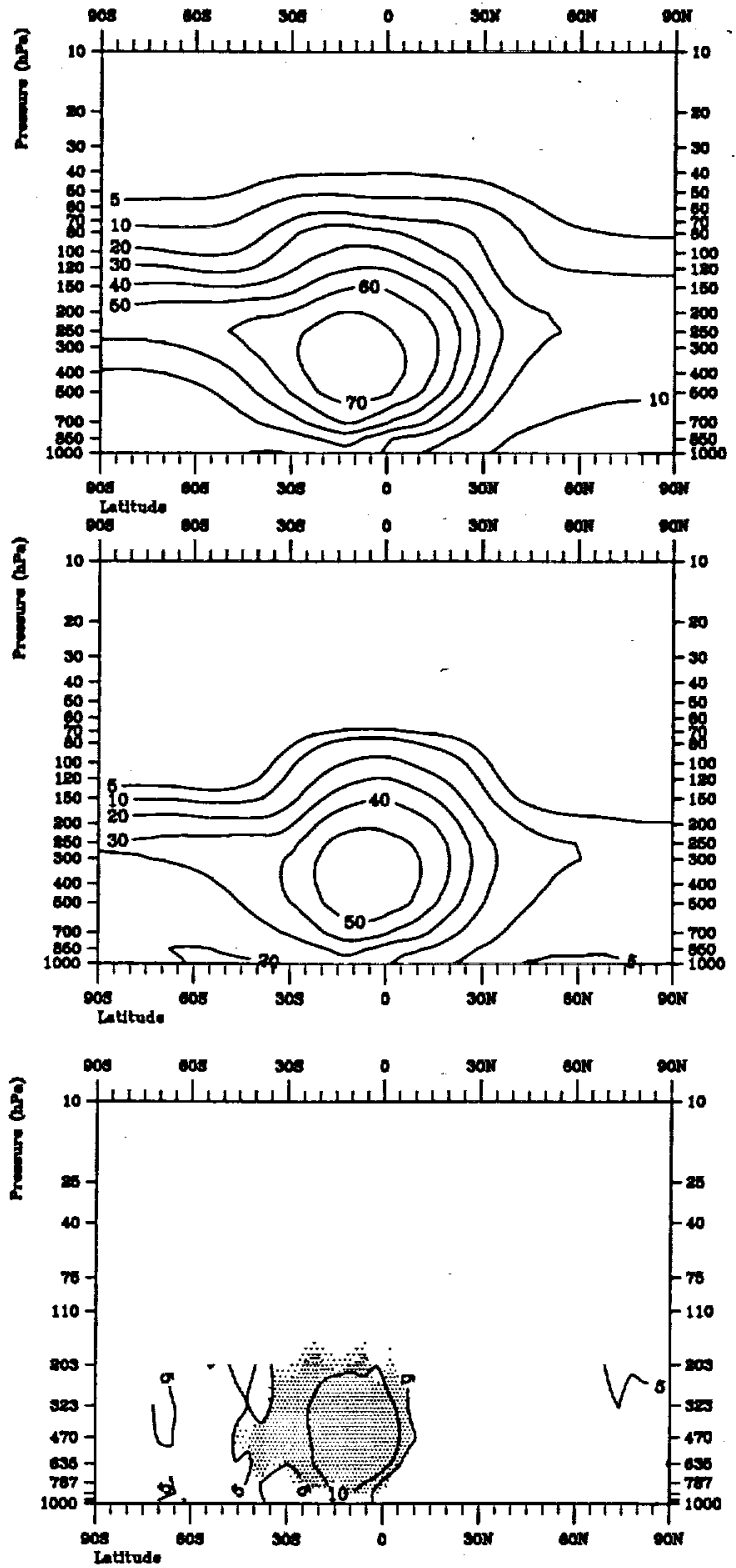